\title{
Transfer of Polychlorophenol-Degrading Rhodococcus chlorophenolicus (Apajalahti et al. 1986) to the Genus Mycobacterium as Mycobacterium chlorophenolicum comb. nov.
}

\author{
MAX M. HÄGGLBLOM, ${ }^{1 *}$ LIISA J. NOHYNEK, ${ }^{2}$ NORBERTO J. PALLERONI,,${ }^{1,3}$ KAARINA KRONQVIST, ${ }^{2}$ \\ EEVA-LIISA NURMIAHO-LASSILA, ${ }^{4}$ MIRJA S. SALKINOJA-SALONEN, ${ }^{2}$ \\ STEFAN KLATTE, ${ }^{5}$ AND REINER M. KROPPENSTEDT ${ }^{5}$
}

Center for Agricultural Molecular Biology, Rutgers University, New Brunswick, New Jersey $08903^{1}$; Department of Applied Chemistry and Microbiology, ${ }^{2}$ and Department of Electron Microscopy, ${ }^{4}$ University of Helsinki, Helsinki, Finland; Department of Microbiology, New York University of Medical Center, New York, New York 10016 $6^{3}$ and DSM-Deutsche Sammlung von Mikroorganismen und Zellkulturen GmbH, D-38124 Braunschweig, Germany ${ }^{5}$

\begin{abstract}
Three independently isolated polychlorophenol-degrading strains of bacteria were characterized on the basis of chemotaxonomic and nutritional characteristics. Previously, these strains were assigned to the species Rhodococcus chlorophenolicus, which was described on the basis of the properties of one of the strains, strain PCP-IT (T = type strain) (J. H. A. Apajalahti, P. Kärpänoja, and M. S. Salkinoja-Salonen, Int. J. Syst. Bacteriol 36:246-251, 1986). However, the results of analyses of mycolic acids suggested that these organisms should be transferred to the genus Mycobacterium as Mycobacterium chlorophenolicum. These bacteria have meso-diaminopimelic acid, arabinose, and galactose as cell wall constituents, mycolic acids containing 75 to 80 carbon atoms, and a predominant menaquinone with nine isoprenoid units and one hydrogenated double bond. The fatty acids include mainly straight-chain saturated and monounsaturated fatty acids with 10 to 18 carbon atoms and a large proportion of 10 -methyloctadecanoic acid (tuberculostearic acid). The $G+C$ contents of the DNAs of the three strains range from 67 to $69 \mathrm{~mol} \%$.
\end{abstract}

The taxonomy of the mycolic acid-containing actinomycetes has undergone extensive revision in recent years. The use of chemotaxonomy in actinomycete taxonomy has provided reliable and reproducible methods for identifying nocardioform bacteria. Actinomycetes that exhibit wall chemotype IV consisting of meso-diaminopimelic acid as the diamino acid and arabinose and galactose as major sugars (28) and contain mycolic acids have been placed in the families Nocardiaceae (with the genera Nocardia, Rhodococcus, Gordona, and Tsukamurella), Corynebacteriaceae, and Mycobacteriaceae, which form a phylogenetically coherent group (14).

The nocardioform actinomycetes can be differentiated on the basis of the presence and size of their mycolic acids $(14,16$, 31). Corynebacteria have short-chain mycolates (20 to 38 carbon atoms), nocardiae, rhodococci, and gordonae have mycolates of intermediate size ( 46 to 60,34 to 52 , and 48 to 66 carbon atoms, respectively), and tsukamurellae and mycobacteria have long-chain mycolates (64 to 78 and 60 to 90 carbon atoms, respectively). Menaquinone composition is another taxonomic marker that can be used for classifying nocardioform bacteria and is somewhat genus specific. In particular, true Nocardia spp. contain hexahydrogenated menaquinone 8 in which the two units at the end are cyclized $\left[\mathrm{MK}-8\left(\mathrm{H}_{4 \text { wcycl }}\right)\right]$ as the predominant component (7). Members of the genus Corynebacterium contain either MK-8 $\left(\mathrm{H}_{2}\right)$ or MK-9 $\left(\mathrm{H}_{2}\right)$, Tsukamurella spp. contain MK-9, Rhodococcus spp. contain MK-8 $\left(\mathrm{H}_{2}\right)$, and Gordona and Mycobacterium spp. contain MK-9 $\left(\mathrm{H}_{2}\right)$ as the predominant menaquinones (14).

Nocardioform actinomycetes are widely distributed in nature and have been isolated from soil, freshwater, marine

\footnotetext{
${ }^{*}$ Corresponding author. Mailing address: Center for Agricultural Molecular Biology, Rutgers University, P.O. Box 231, New Brunswick, NJ 08903. Fax: (908) 932-6535. Phone: (908) 932-1585. Electronic mail address: haggblom@mbcl.rutgers.edu.
}

water, and sediments (16). Rhodococci, nocardiae, and mycobacteria have wide catabolic potentials and are able to use a range of organic compounds as sole sources of carbon and energy. These organisms have been found to degrade a variety of aliphatic hydrocarbons and aromatic compounds and to transform several xenobiotic compounds $(12,17,18,21,23,25$, $34,39,51)$.

Apajalahti et al. (1) isolated a pentachlorophenol-mineralizing actinomycete, which they described as the new species Rhodococcus chlorophenolicus, with strain PCP-I as the type strain. A recent analysis of the mycolic acids of this organism revealed that they are longer than originally reported and that the species should be placed in the genus Mycobacterium. In this paper we describe chemotaxonomic and nutritional characteristics of three independently isolated chlorophenol-degrading strains and provide additional information on type strain PCP-I. We propose that $R$. chlorophenolicus should be transferred to the genus Mycobacterium as Mycobacterium chlorophenolicum.

\section{MATERIALS AND METHODS}

Bacterial strains. The bacterial strains used in this study are listed in Table 1. The chlorophenol-degrading bacteria were independently isolated from enrichment cultures prepared with chlorophenol-contaminated soil and sludge obtained from different geographic locations in Finland. Strain PCP-I ${ }^{\mathrm{T}}(R$. chlorophenolicus) ( $\mathrm{T}=$ type strain) was isolated from a mixed culture that originated from a chlorophenol-contaminated lake sediment sample (1). A second strain, designated CG-1, was isolated from a tetrachloroguaiacol-degrading mixed culture obtained from a bark chip biofilter inoculated with sludge from an aerated lagoon in which pulp and paper mill effluents were treated (24), and a third strain, designated CP-2, was isolated from a pentachlorophenol-degrading mixed culture obtained from chlorophenol-contaminated soil $(24,47,48)$. Strains 
TABLE 1. Strains used in this study

\begin{tabular}{|c|c|c|}
\hline Taxon & Strain & Origin \\
\hline \multirow[t]{3}{*}{$\begin{array}{l}\text { Mycobacterium } \\
\text { chlorophenolicum }\end{array}$} & $\begin{array}{c}\text { PCP-I }{ }^{\mathrm{T}}(=\mathrm{DSM} \\
\left.43826^{\mathrm{T}}\right)\end{array}$ & Lake sediment \\
\hline & CG-1 (= DSM 5146) & Sludge \\
\hline & CP-2 (= DSM 4598) & Soil \\
\hline Rhodococcus rhodochrous & DSM $43241^{\mathrm{T}}$ & \\
\hline R. rhodochrous & IMET 7018 & \\
\hline R. coprophilus & IMET 7375 & \\
\hline$R$. erythropolis & DSM $43066^{\mathrm{T}}$ & \\
\hline Gordona rubropertincta & IMET 7372 & \\
\hline Corynebacterium lilium & DSM $20137^{\mathrm{T}}$ & \\
\hline Mycobacterium phlei & DSM $43239^{\mathrm{T}}$ & \\
\hline M. fortuitum & CG-2 (= DSM 5129) & \\
\hline Nocardia brasiliensis & DSM 43009 & \\
\hline Saccharopolyspora hirsuta & DSM $43463^{T}$ & \\
\hline
\end{tabular}

CG-1 and CP-2 were tentatively identified as Rhodococcus spp. (24). All three bacterial strains were shown to degrade several polychlorinated phenols, guaiacols, and syringols $(2,19,20$, 24).

Media. For chemical analysis the bacteria were grown in DSM-65 medium ( $4 \mathrm{~g}$ of glucose per liter, $4 \mathrm{~g}$ of yeast extract per liter, $4 \mathrm{~g}$ of malt extract per liter; $\mathrm{pH}$ 7.2) (10) or in a mineral salts medium (43) enriched with vitamins (43), trace elements (5), and $0.1 \%$ (wt/vol) glucose, $0.1 \%$ (wt/vol) mannose, or $0.1 \%$ (wt/vol) sorbitol as a carbon source; the cultures were incubated at $28^{\circ} \mathrm{C}$. For nutritional screening of strains, we used a basal salts medium that lacked organic growth factors (36) and was solidified by adding $1.8 \%$ Difco agar. Each carbon source was added aseptically from a sterile concentrated solution to a final concentration of $0.2 \%$ (wt/vol). Lower concentrations of some aromatic compounds were also tested. Naphthalene was provided in the vapor phase by incubating plates in a desiccator with a few naphthalene crystals. Dilute suspensions of fresh bacterial cultures were inoculated by using a multiple-point inoculator. The plates were incubated at $30^{\circ} \mathrm{C}$, and the results were recorded after $3,5,7$, and 14 days by using an inoculated plate containing no carbon substrate for comparison. The results were recorded as follows: + (good growth), - (growth not greater than the background level), \pm (poor growth), and $\mathrm{M}$ (growth after mutation). Growth on hexadecane was tested in liquid medium to which a few drops of sterile hexadecane had been added. The flasks were incubated at $30^{\circ} \mathrm{C}$ on a rotatory shaker.

Other physiological tests. Nitrate reduction and acid phosphatase and aryl sulfatase activities were determined by using the procedures described in Methods for General and Molecular Bacteriology (40) and Procedures for the Isolation and Identification of Mycobacteria (49). We used a diagnostic kit (catalog no. 104; Sigma Chemical Co., St. Louis, Mo.) to determine acid phosphatase activity.

Cell wall sugars. Cell wall sugars were determined as alcohol acetylates by gas-liquid chromatography. A $2-\mathrm{mg}$ portion of lyophilized washed cells was hydrolyzed in $100 \mu \mathrm{l}$ of $0.1 \mathrm{M} \mathrm{HCl}$ at $100^{\circ} \mathrm{C}$ for $48 \mathrm{~h}$. The hydrolysate was cooled and was then diluted with $2 \mathrm{ml}$ of $\mathrm{H}_{2} \mathrm{O}$, neutralized with Amberlite IRA 410 resin $\left(\mathrm{HCO}_{3}{ }^{-}\right.$form $)$, and eluted through a column containing the same resin. The column was washed with $5 \mathrm{ml}$ of $\mathrm{H}_{2} \mathrm{O}$, and the eluate was evaporated to dryness in a rotatory evaporator. The residue was dissolved in $200 \mu \mathrm{l}$ of $\mathrm{H}_{2} \mathrm{O}, 100 \mu \mathrm{l}$ of $5 \%$ $\mathrm{NaBH}_{4}$ (in $10 \mathrm{mM} \mathrm{NaOH}$ ) was added, and the mixture was incubated overnight at room temperature in the dark. The sample was neutralized with $6 \mathrm{~N} \mathrm{HCl}, 15 \mathrm{ml}$ of $5 \%$ acetic acid in methanol was added, and the sample was evaporated to dryness in a rotatory evaporator (this procedure was repeated twice) and finally evaporated to dryness with $5 \mathrm{ml}$ of pyridine. The residue was dissolved in $0.5 \mathrm{ml}$ of pyridine, $0.5 \mathrm{ml}$ of acetic anhydride was added, and the mixture was incubated for 30 min at $100^{\circ} \mathrm{C}$. After acetylation the sample was evaporated to dryness twice, after $10 \mathrm{ml}$ of methanol and then $5 \mathrm{ml}$ of $\mathrm{H}_{2} \mathrm{O}$ were added. The sample was finally dissolved in $5 \mathrm{ml}$ of $\mathrm{CHCl}_{3}$, washed three times with $\mathrm{H}_{2} \mathrm{O}$, and dried with $\mathrm{Na}_{2} \mathrm{SO}_{4}$. The acetylated reduced sugars were analyzed by gas-liquid chromatography with a model HP5880 gas chromatograph (HewlettPackard Co., Palo Alto, Calif.) equipped with a type HP-1 capillary column (Hewlett-Packard Co.) and a mass selective detector (model HP5970A; Hewlett-Packard Co.). D-Arabinose, D-galactose, D-glucose, and D-xylose were used as reference compounds for the sugar analysis.

Cell wall diamino acids. We used previously described procedures to analyze the amino acids of whole-cell hydrolysates (41).

Mycolic acids. For the mycolic acid analysis, strain PCP- $\mathrm{I}^{\mathrm{T}}$ was grown in shake cultures at $28^{\circ} \mathrm{C}$ for 3 days in brain heart infusion broth (Difco), heat killed, harvested by centrifugation, and freeze-dried after the preparations were washed with distilled water. Mycolic acid methyl esters were prepared by whole-cell acid methanolysis as described by Minnikin et al. (32) or by alkaline methanolysis (33). For acid methanolysis 50 mg of dry cell material was mixed with $5 \mathrm{ml}$ of dry methanoltoluene-sulfuric acid $(25: 25: 1, \mathrm{vol} / \mathrm{vol} / \mathrm{vol})$ and kept at $75^{\circ} \mathrm{C}$ overnight. After the preparation was cooled to room temperature, $1 \mathrm{ml}$ of hexane was added, and the mixture was vigorously shaken. After phase separation, the upper hexane layer was passed through a Pasteur pipette filled with ammonium hydrogen carbonate to remove residual sulfuric acid. The eluate was evaporated under nitrogen to a final volume of approximately $100 \mu \mathrm{l}$ for thin-layer chromatography (TLC). Alkaline methanolysis of whole-cell material was performed as described by Minnikin et al. (33).

The acid methanolysates were analyzed by both one-dimensional TLC and two-dimensional TLC on high-performance Silica Gel 60 plates (catalog no. 5631; E. Merck, Darmstadt, Germany). One-dimensional TLC was carried out by developing the plates in petroleum ether $\left(\mathrm{bp}, 60\right.$ to $\left.80^{\circ} \mathrm{C}\right)$-diethyl ether (85:15, vol/vol) (31). For two-dimensional TLC petroleum ether (bp, 60 to $80^{\circ} \mathrm{C}$ )-acetone $(95: 5, \mathrm{vol} / \mathrm{vol})$ was used as the solvent for triple development in the first direction, and toluene-acetone $(97: 3$, vol $/ \mathrm{vol})$ was used for single development in the second direction. The separated components were visualized by treating the plates with molybdatophosphoric acid (E. Merck) and then heating them at $120^{\circ} \mathrm{C}$ for $15 \mathrm{~min}$.

Fatty acid analysis. Whole-cell fatty acids were analyzed as methanol esters by gas chromatography. The bacteria were grown on Middelbrook $7 \mathrm{H} 10$ agar for 7 days at $28^{\circ} \mathrm{C}$. Then 40 to $80 \mathrm{mg}$ (wet weight) of cells was harvested and saponified, and fatty acid methyl esters were prepared as described previously (30). The analysis was performed by using a model HP5890A gas chromatograph (Hewlett-Packard Co.) connected to a computer and the MIDI Microbial Identification System (MIDI Inc., Newark, Del.) for identification of fatty acids (we used the Microbial Identification System library for mycobacteria [MIS MYCO Library]).

Polar lipids. Polar lipids were extracted, examined by twodimensional TLC, and identified by using previously described procedures (34).

Menaquinones. Menaquinones were extracted from $150 \mathrm{mg}$ of dried cells with chloroform-methanol (2:1) and were purified by TLC (Silica Gel 60; E. Merck) as described pre- 

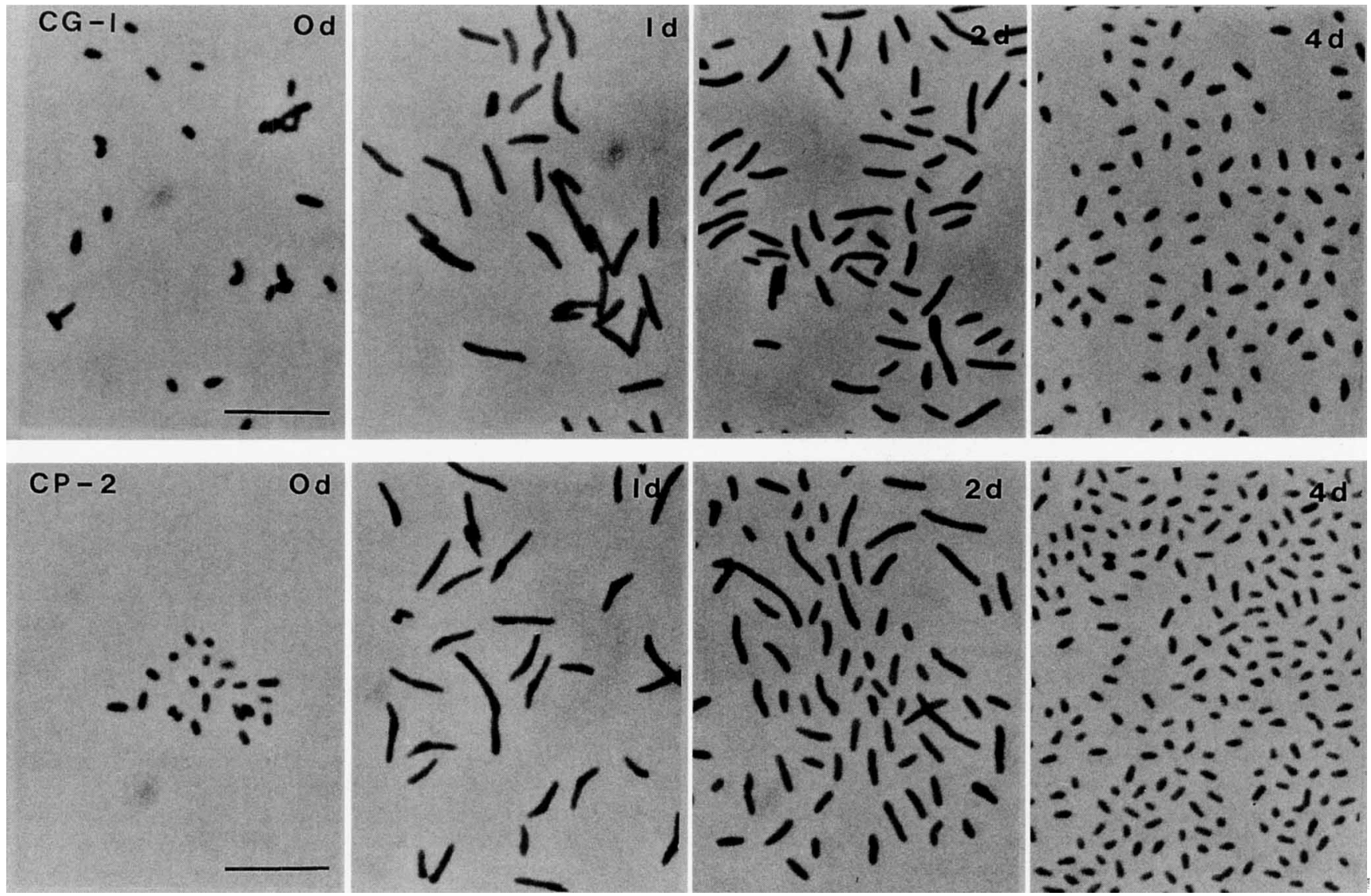

FIG. 1. Morphological cycles of $M$. chlorophenolicum CG-1 and CP-2 grown on malt extract-yeast extract-glucose agar at $28^{\circ} \mathrm{C}$ for $0,1,2$, and 4 days $(0 \mathrm{~d}, 1 \mathrm{~d}, 2 \mathrm{~d}$, and $4 \mathrm{~d}$, respectively). Phase-contrast micrographs of live cells. Bars $=10 \mu \mathrm{m}$.

viously (8). The sizes of menaquinones were determined by reverse-phase TLC (RP-18; $\mathrm{F}_{254} ; \mathrm{E}$. Merck), using acetonewater (99:1, vol/vol) as the solvent (9), and by high-performance liquid chromatography (HPLC). The liquid chromatograph which we used consisted of a model 510 HPLC pump (Millipore Corp., Waters Chromatography Div., Milford, Mass.) a Waters model 700 satellite WISP sample injector, a model HP1050 Series multiple-wavelength detector (HewlettPackard Co.), and a Waters baseline chromatography workstation. For analysis, samples were dissolved in the mobile phase, filtered (nylon Acrodisk 13 filter; pore size, $0.45 \mu \mathrm{m}$; Gelman), and separated on a Cosmosil reverse-phase C18 column (particle size, $5 \mu \mathrm{m} ; 4.6 \mathrm{~mm}$ [inside diameter] by $150 \mathrm{~mm}$; Nakarai Chemicals Ltd., Kyoto, Japan) by using a methanol- $n$-butyl chloride $(80: 20, \mathrm{vol} / \mathrm{vol})$ solvent system at a flow rate of 1.0 $\mathrm{ml} / \mathrm{min}$. Menaquinones were detected at $269 \mathrm{~nm}$ (band width, $4 \mathrm{~nm}$ ), and the reference wavelength used was $450 \mathrm{~nm}$ (band width, $80 \mathrm{~nm}$ ). In a separate experiment isoprenoid quinones were extracted and purified by using the small-scale integrated procedure of Minnikin et al. (34). Dried preparations were dissolved in $200 \mu \mathrm{l}$ of isopropanol and 1- to 10- $\mu$ l amounts were separated without further purification by HPLC by using a Lichrosorb RP-18 column at $40^{\circ} \mathrm{C}$ and acetonitrile-isopropanol $(65: 35$, vol/vol) as the solvent (27).

DNA base composition. The cells from $100 \mathrm{ml}$ of culture grown for 2 to 3 days were collected, washed with Tris-EDTA buffer (50 mM Tris- $\mathrm{HCl}, 20 \mathrm{mM}$ EDTA; $\mathrm{pH} 8$ ), and resuspended in 1 to $5 \mathrm{ml}$ of the same buffer. Lysozyme was added to a final concentration of $2 \mathrm{mg} \mathrm{ml}^{-1}$, and the suspension was incubated at $37^{\circ} \mathrm{C}$ overnight. The cells were lysed by adding $2 \%$ sodium dodecyl sulfate and incubating the preparation for $1 \mathrm{~h}$. The DNA was precipitated by adding 0.1 volume of $3 \mathrm{M}$ sodium acetate and 0.54 volume of isopropanol and then dissolved in dilute $1 \times \mathrm{SSC}(15 \mathrm{mM} \mathrm{NaCl}$ plus $1.5 \mathrm{mM}$ sodium citrate, $\mathrm{pH} 7.0$ ). Pronase was added to a concentration of $2 \mathrm{mg}$ $\mathrm{ml}^{-1}$, and the mixture was incubated for $4 \mathrm{~h}$. The DNA solution was extracted once with 1 volume of phenol and 1 volume of chloroform. The DNA was precipitated with 2 volumes of ethanol $\left(-20^{\circ} \mathrm{C}\right)$, redissolved in $1 \times \mathrm{SSC}$, and then digested with RNase I ( $\left.50 \mu \mathrm{g} \mathrm{ml}^{-1}\right)$ and RNase $\mathrm{T}_{1}\left(30 \mathrm{U} \mathrm{ml}^{-1}\right)$ for $30 \mathrm{~min}$ at $37^{\circ} \mathrm{C}$. The phenol and chloroform extractions and precipitation with ethanol were repeated, and the DNA was dissolved in $1 \times$ SSC. The DNA was digested with nuclease $P_{1}$ and bacterial alkaline phosphatase to the nucleoside level and was analyzed by HPLC as described by Kaneko et al. (26), using a Cosmosil 5C18 column (Nakarai Chemicals, Ltd.) and a Spectroflow 400 solvent delivery system (Kratos Analytical Instruments, Ramsey, N.J.).

Phage sensitivity testing. The clearing effect of Rhodococcus phages was studied by using a method modified from the method of Prauser (37) and the following phages and host strains: phage IMET 5039 and host Rhodococcus rhodochrous IMET 7018, phage IMET 5042 and [host Gordona rubropertincta (synonym, Rhodococcus rubropertinctus) IMET 7372], and phage IMET 5046 and host Rhodococcus coprophilus IMET 7375. The host strains and strains CG-1, CP-2, and 

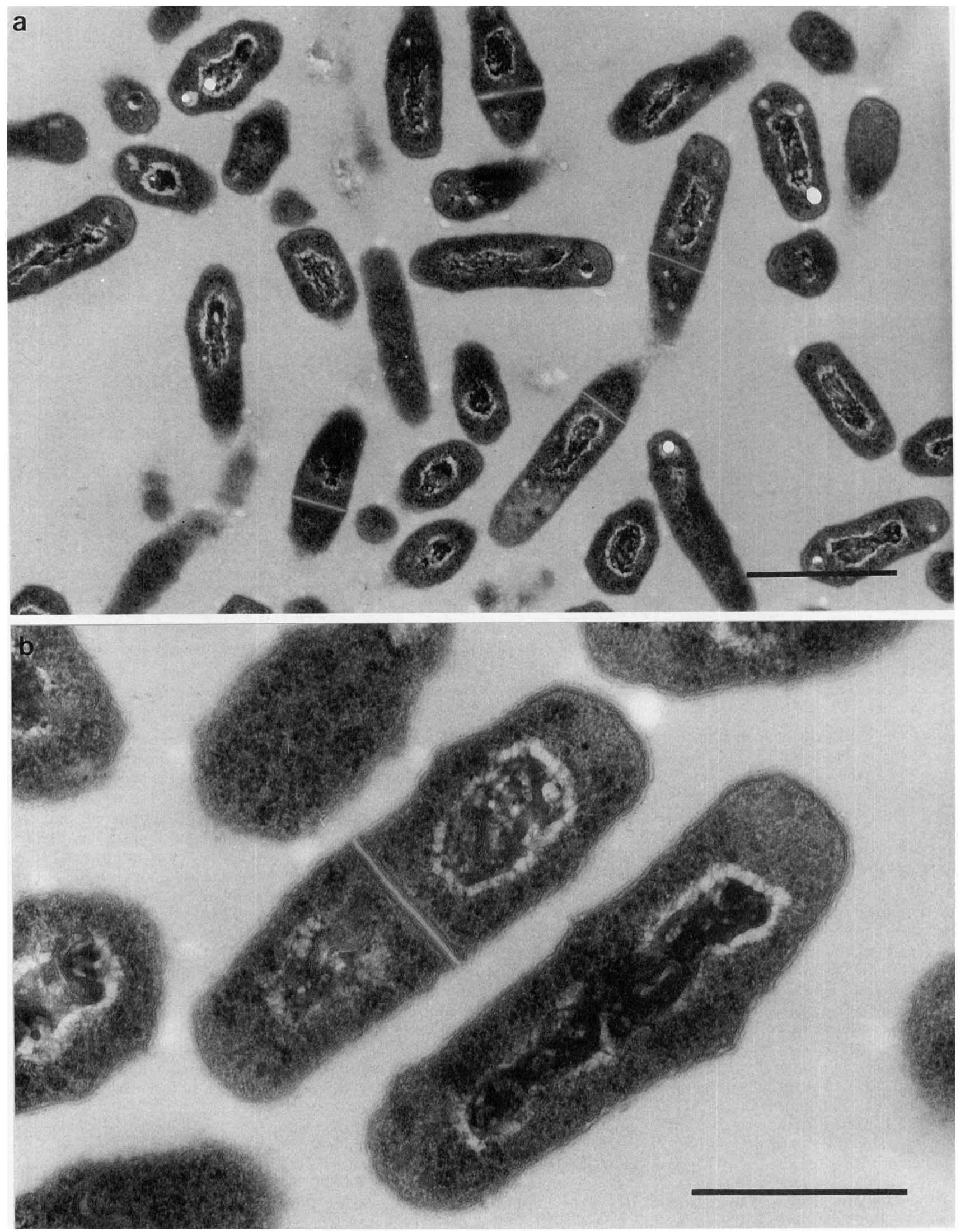

FIG. 2. Electron micrographs of thin sections of $M$. chlorophenolicum CG-1 grown on malt extract-yeast extract-glucose agar at $28^{\circ} \mathrm{C}$ for 1 day. (a) $\mathrm{Bar}=1 \mu \mathrm{m}$. (b) $\mathrm{Bar}=0.5 \mu \mathrm{m}$. 


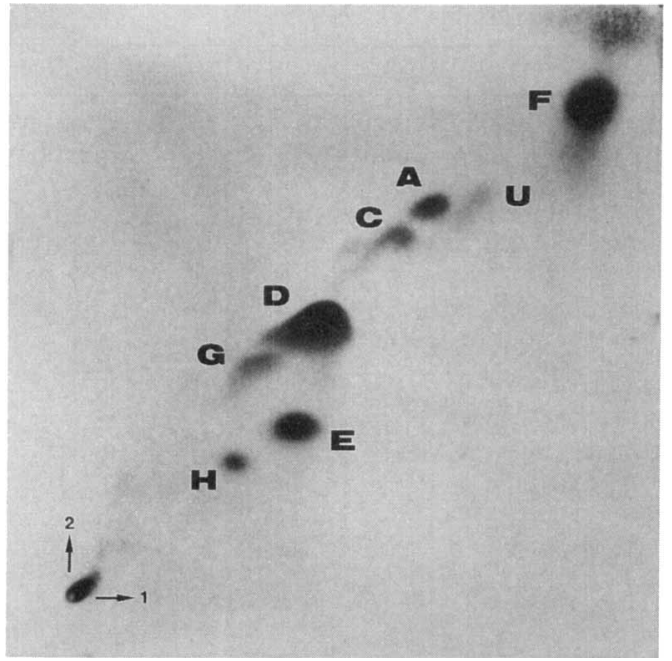

FIG. 3. Two-dimensional TLC of methanolysates of strain PCP-I ${ }^{\mathrm{T}}$ after acid hydrolysis. Abbreviations: A, $\alpha$-mycolates; C, keto-mycolates; C, wax ester mycolates; D, $\Omega$-carboxymycolates; E, alcohol homologs of 2-eicosanol; F, fatty acid methyl esters; $G$ and $H$, unknowns; $\mathrm{U}$, unidentified long-chain compound that could be removed by a methanolic wash.

PCP-I ${ }^{\mathrm{T}}$ were grown overnight in DSM-65 medium, $0.2 \mathrm{ml}$ of each overnight culture was suspended in $5 \mathrm{ml}$ of melted DSM-65 soft agar $\left(45^{\circ} \mathrm{C}\right)$, and then each preparation was spread on a DSM-65 agar plate. The phage suspensions were spotted onto plates in 6- $\mu \mathrm{l}$ amounts. The plates were incubated for 2 days at $28^{\circ} \mathrm{C}$ and then examined for clearing.

Microscopy. For light microscopy the strains were grown on DSM-65 agar, and morphology was studied daily for 1 week. Slide preparations were made by aseptically inverting a $1-\mathrm{cm}^{2}$ slice of agar on a glass slide and then removing the agar slice and adding 1 drop of water. The bacteria were studied by phase-contrast microscopy by examining the wet mounts with a Jenaval Zeiss mf-AKS microscope (Carl Zeiss, Jena, Germany).

For electron microscopy the strains were grown for 1 day on DSM-65 agar. Samples were prefixed with 3\% (vol/vol) glutaraldehyde (Leiras, Turku, Finland) in $0.1 \mathrm{M}$ sodium phosphate

TABLE 2. Whole-cell fatty acid compositions of M. chlorophenolicum strains

\begin{tabular}{lccc}
\hline \multirow{2}{*}{ Fatty acid $^{a}$} & \multicolumn{3}{c}{$\%(\mathrm{wt} / \mathrm{vol})$ of total in: } \\
\cline { 2 - 4 } & Strain PCP-I $^{\mathrm{T}}$ & Strain CP-2 & Strain CG-1 \\
\hline 14:0 & 5 & 6 & 8 \\
$16: 0$ & 18 & 22 & 31 \\
$16: 1$ cis 9 & 2 & 2 & 6 \\
$16: 1$ cis 10, trans 9 & 8 & 9 & 6 \\
18:0 & 1 & 1 & 4 \\
18:1 cis 9 & 23 & 10 & 18 \\
18:0 Alc & 8 & 23 & 6 \\
TBSA & 14 & 15 & 5 \\
20:0 Alc & 14 & 7 & 8 \\
Others & 7 & 5 & 8 \\
\hline
\end{tabular}

a Abbreviations: 14:0, tetradecanoate; 16:0, hexadecanoate; 16:1 cis9, cis-9hexadecenoate; $16: 1$ cis 10 ,trans 9 , cis-10- or trans-9-hexadcenoate; 18:0, octadecanoate; 18:1 cis 9 , cis-9-octadecenoate; 18:0 Alc, octadecanol (summed feature 18:0 Alc plus 17:1); TBSA, tuberculostearic acid $\left(10 \mathrm{Me}-\mathrm{C}_{18}\right) ; 20: 0 \mathrm{Alc}$, eicosanol (summed feature 20:0 Alc plus 19:1). buffer ( $\mathrm{pH} \mathrm{7.2)} \mathrm{for} 2 \mathrm{~h}$, washed three times with the same buffer, and postfixed for $2 \mathrm{~h}$ in buffered $1 \%$ (wt/vol) osmium tetroxide. The specimens were dehydrated in a graded series of ethanol and propylene oxide preparations and were embedded in Epon LX-112 (Ladd). Thin sections were cut with a diamond knife on a LKB Ultrotome III ultramicrotome and were double stained with uranyl acetate and lead citrate. The grids were examined with a JEOL model JEM-1200EX electron microscope at an operating voltage of $60 \mathrm{kV}$.

\section{RESULTS AND DISCUSSION}

Colony and cell morphology. On DSM-65 agar strains PCP-I ${ }^{\mathrm{T}}$, CG-1, and CP-2 formed yellow or orange, slightly mucoid colonies after 4 to 8 days of incubation. The morphological cycle determined for strains CG-1 and CP-2 when they were grown on DSM-65 agar is shown in Fig. 1. The inoculum form was coccoid. After 1 day of incubation unbranched rods predominated, which after further incubation fragmented into cocci. Figure 2 shows electron micrographs of 1-day-old cultures of strain CG-1. The cells were unbranched rods of varying lengths with diameters of 0.6 to $0.7 \mu \mathrm{m}$ and were surrounded by a capsule-like material; this morphology was similar to strain PCP-I ${ }^{\mathrm{T}}$ morphology (1). The strains were aerobic, and young cells were gram positive.

Wall chemotype. The cell walls of strains PCP-I ${ }^{\mathrm{T}}, \mathrm{CG}-1$, and $\mathrm{CP}-2$ contained meso-diaminopimelic acid as a major constituent. The cell wall sugars were arabinose and galactose. Thus, the cell wall chemotype of these strains was type IV (29).

Mycolic acids. The mycolic acids of strain PCP-I ${ }^{\mathrm{T}}$ were originally reported to contain 33 to 43 carbon atoms (1), and this strain was classified as a new Rhodococcus species. Our analysis of the mycolic acids of strains PCP-I ${ }^{\mathbf{T}}, \mathrm{CG}-1$, and $\mathrm{CP}-2$ indicated that the mycolic acids of these organisms are 75 to 80 carbon atoms long, a characteristic that is diagnostic for members of the genus Mycobacterium.

The results of our two-dimensional analysis of whole-cell methanolysates (Fig. 3) indicated that strain PCP-I ${ }^{\mathrm{T}}$ produced a TLC pattern containing $\alpha$-mycolate (compound A), ketomycolate (compound C), and wax ester mycolates, as indicated by the cleavage products $\Omega$-carboxymycolates (compound $\mathrm{D}$ ) and long-chain alcohols (compound $E$ ), homologs of 2-eicosanol. In addition, an unidentified long-chain compound (compound $\mathrm{U}$ ), which may have been a long-chain alcohol, was detected after acidic hydrolysis as well as after alkaline hydrolysis.

Menaquinones. In our reverse-phase TLC analysis the menaquinones of strains CG-1 and CP-2 cochromatographed with the menaquinones of strain PCP-I ${ }^{\mathrm{T}}\left(R_{f}, 0.56\right.$ to 0.57$)$, which contains MK- $9\left(\mathrm{H}_{2}\right)$ as its major menaquinone. The $R_{f}$ values of these menaquinones were lower than the $R_{f}$ values of the menaquinones of $R$. rhodochrous $\left[\mathrm{MK}-8\left(\mathrm{H}_{2}\right)\right]\left(R_{f}, 0.60\right)$ and Nocardia brasiliensis [MK-8( $\left(\mathrm{H}_{4}\right.$ wcycl $\left.)\right]\left(R_{f}, 0.58\right)$ and higher than the $R_{f}$ value of the menaquinone of Saccharopolyspora hirsuta [MK-9 $\left.\left(\mathrm{H}_{4}\right)\right]\left(R_{f}, 0.53\right)$. In our HPLC analysis the menaquinones of strains CG-1 and CP-2 cochromatographed with the menaquinone of strain PCP-I ${ }^{\mathrm{T}}$. Thus, strains PCP-I ${ }^{\mathrm{T}}$, CG-1, and CP-2 thus contain MK-9 $\left(\mathrm{H}_{2}\right)$ as their major menaquinone.

Fatty acids. The fatty acid profiles of strains PCP-I ${ }^{\mathrm{T}}, \mathrm{CP}-2$, and CG-1 were determined by using gas-liquid chromatography and the Microbial Identification System. The levels of the main whole-cell fatty acids are shown in Table 2 . The strains contained mainly straight-chain saturated and monounsaturated fatty acids with 14 to 20 carbon atoms, as well as substantial amounts of 10-methyloctadecanoic acid (tubercu- 
TABLE 3. Characteristics of $M$. chlorophenolicum strains

\begin{tabular}{|c|c|c|c|}
\hline Characteristic & Strain PCP-I ${ }^{\mathbf{T}}$ & Strain $\mathrm{CP}-2$ & Strain CG-1 \\
\hline Morphology ${ }^{a}$ & Rod to coccus & Rod to coccus & Rod to coccus \\
\hline Pigmentation & Orange & Yellow, orange & Yellow, orange \\
\hline \multicolumn{4}{|l|}{ Lipid characteristics } \\
\hline No. of carbon atoms in mycolic acids & $75-80$ & $>60$ & $>60$ \\
\hline Predominant menaquinone & MK-9( $\left.\mathrm{H}_{2}\right)$ & MK-9( $\left.\mathrm{H}_{2}\right)$ & MK-9 $\left(\mathrm{H}_{2}\right)$ \\
\hline $\mathrm{G}+\mathrm{C}$ content of DNA $(\mathrm{mol} \%)$ & 69.2 & 67.5 & 67.7 \\
\hline \multicolumn{4}{|l|}{ Growth at ${ }^{a}$ : } \\
\hline $10^{\circ} \mathrm{C}$ & $-{ }^{b}$ & - & - \\
\hline $18^{\circ} \mathrm{C}$ & + & + & + \\
\hline $28^{\circ} \mathrm{C}$ & + & + & + \\
\hline $37^{\circ} \mathrm{C}$ & + & + & + \\
\hline $45^{\circ} \mathrm{C}$ & - & - & - \\
\hline Nitrate reduction & - & - & - \\
\hline Acid phosphatase activity & \pm & + & + \\
\hline Arylsulfatase activity & \pm & + & + \\
\hline \multicolumn{4}{|l|}{ Growth in the presence of ${ }^{a}$ : } \\
\hline Sodium chloride $(0.003 \%$, wt/vol $)$ & + & + & + \\
\hline Sodium chloride $(3.0 \%$, wt/vol) & + & + & + \\
\hline Sodium chloride $(7.0 \%, \mathrm{wt} / \mathrm{vol})$ & - & - & - \\
\hline
\end{tabular}

${ }^{a}$ Data for strain PCP-I ${ }^{\mathrm{T}}$ from reference 1 .

${ }^{b}+$, good growth or activity; \pm , poor activity; - , no growth or activity.

lostearic acid). The identities of the major fatty acids were also confirmed by gas-liquid chromatography-mass spectrometry. The fatty acid profiles of strains PCP-I ${ }^{\mathrm{T}}$, CP-2, and CG-1 did not match the profile of any of the rapidly growing mycobacteria in the MIS MYCO Library, including Mycobacterium aurum, Mycobacterium chelonae subsp. abscessus, Mycobacterium chelonae subsp. chelonae, Mycobacterium flavescens, $\mathrm{My}$ cobacterium fortuitum, Mycobacterium parafortuitum, Mycobacterium smegmatis, and Mycobacterium thermoresistibile.

Polar lipids. Two-dimensional TLC of whole-cell extracts of PCP-I ${ }^{\mathrm{T}}$, CG-1, and CP-2 produced identical patterns. Each pattern was composed of phosphatidylethanolamine, phosphatidylglycerol, diphosphatidylglycerol, phosphatidylinositol, and phosphatidylinositolmannosides. Phosphatidylcholine and glucosamine-containing phospholipid were not detected. This phospholipid pattern is found in the families Nocardiaceae and Mycobacteriaceae but not in the Corynebacteriaceae (14).

G+C content of DNA. The base compositions of the DNAs of strains PCP-I ${ }^{\mathrm{T}}$, CG-1, and CP-2 were determined by HPLC by using $R$. rhodochrous DSM $43241^{\mathrm{T}}$ as the reference strain. The $\mathrm{G}+\mathrm{C}$ content of strain CG-1 was $67.7 \mathrm{~mol} \%$, the $\mathrm{G}+\mathrm{C}$ content of strain CP-2 was $67.5 \mathrm{~mol} \%$, and the $\mathrm{G}+\mathrm{C}$ content of strain PCP-I ${ }^{\mathrm{T}}$ was $69.2 \mathrm{~mol} \%$. The $\mathrm{G}+\mathrm{C}$ content determined for $R$. rhodochrous was $68.8 \mathrm{~mol} \%$, which is within the range reported for the species (67 to $70 \mathrm{~mol} \%$ ) (13).

Physiological and growth characteristics. The physiological and growth characteristics of strains PCP-I ${ }^{\mathbf{T}}, \mathrm{CG}-1$, and $\mathrm{CP}-2$ are shown in Table 3. Growth occurred at 18,28 , and $37^{\circ} \mathrm{C}$, but not at 10 or $45^{\circ} \mathrm{C}$; optimum growth occurred at $28^{\circ} \mathrm{C}$. At $28^{\circ} \mathrm{C}$ growth occurred in the presence of 0.003 and $3 \%$ sodium chloride, but not in the presence of $7 \%$ sodium chloride. The list of substrates which we used for screening included a selection of biochemically important compounds which are either good substrates for a number of bacteria or are key intermediates in well-known biochemical pathways. We found that strains PCP-I ${ }^{\mathrm{T}}$ and $\mathrm{CP}-2$ were very similar and that strain CG-1 differed from these strains in only a limited number of characteristics. Most of the variations were observed in substrates that were very poorly utilized. The nutritional spectra revealed the same limitations found in other related grampositive organisms. Despite their ubiquitous presence in many different habitats and their ability to survive under extreme conditions, the nocardioform actinomycetes do not approach the remarkable nutritional versatility with low-molecularweight organic compounds that the aerobic pseudomonads exhibit $(15,38,42)$. In nature the nocardioform actinomycetes may survive at the expense of compounds that are not normally utilized by the fast-growing organisms in natural environments.

Phage sensitivity. Rhodococcus phages IMET 5039, IMET 5042, and IMET 5046 caused lysis of their respective host strains. Phage IMET 5042 also caused clearing of $R$. coprophilus IMET 7375, and phage IMET 5046 also caused clearing of $R$. rhodochrous IMET 7018 and G. rubropertincta IMET 7372. Strains CG-1, CP-2, and PCP-I ${ }^{\mathrm{T}}$ were not sensitive to any of the phages.

Taxonomy. Strains PCP-I ${ }^{\mathbf{T}}$, CG-1, and CP-2 have the major characteristics of the genus Mycobacterium. All three strains are gram positive, produce yellow or orange pigments, and have a coccus-to-rod-to-coccus morphological cell cycle. Strains PCP-I ${ }^{\mathrm{T}}$, CG-1, and CP-2 have type IV cell walls as described by Lechevalier and Lechevalier (29), which contain meso-diaminopimelic acid, arabinose, and galactose. Mycolic acids are present and contain 75 to 80 carbon atoms. The types of mycolic acids present include $\alpha$-mycolates, keto-mycolates, and wax ester mycolates, which are characteristic of several mycobacteria, including Mycobacterium phlei, Mycobacterium avium, and Mycobacterium terrae $(11,33)$. The predominant menaquinones are menaquinones with nine isoprenoid units and one hydrogenated double bond $\left[\mathrm{MK}-9\left(\mathrm{H}_{2}\right)\right]$. The fatty acids include mainly straight-chain saturated and monounsaturated fatty acids with 10 to 18 carbon atoms and large amounts of 10-methyloctadecanoic acid (tuberculostearic acid). Our fatty acid analysis revealed no species match when the MIS MYCO Library was used. Combined with the phenotypic and nutritional characteristics shown in Tables 3 and 4, the characteristics described above indicate that strains PCP$\mathrm{I}^{\mathrm{T}}, \mathrm{CG}-1$ and $\mathrm{CP}-2$ can be distinguished from other rapidly growing Mycobacterium species $(44,50)$. In addition, the nucleotide sequence of the $16 \mathrm{~S}$ rRNA of strain PCP-I ${ }^{\mathrm{T}}$ exhibits a high level of homology with the 16S rRNA genes of mycobacteria, and the position of strain PCP-I ${ }^{\mathrm{T}}$ appears to be closer to mycobacteria than to the genus Rhodococcus (6). We 
TABLE 4. Nutritional characterization of three M. chlorophenolicum strains

\begin{tabular}{|c|c|c|c|}
\hline Carbon source $^{a}$ & Strain PCP-I ${ }^{\mathrm{T}}$ & Strain CP-2 & Strain CG-1 \\
\hline D-Ribose & $\pm^{b}$ & \pm & - \\
\hline D-Xylose & + & t & + \\
\hline L-Rhamnose & \pm & - & - \\
\hline Glucose & + & + & + \\
\hline Mannose & \pm & + & + \\
\hline Galactose & - & - & M \\
\hline Fructose & + & + & + \\
\hline Trehalose & + & + & \pm \\
\hline Cellobiose & \pm & \pm & - \\
\hline Sucrose & \pm & \pm & - \\
\hline Gluconate & + & + & + \\
\hline Salicin & \pm & \pm & - \\
\hline Acetate & + & + & + \\
\hline Propionate & + & + & $\mathbf{M}$ \\
\hline Butyrate & \pm & \pm & $\mathbf{M}$ \\
\hline Isobutyrate & - & - & \pm \\
\hline Isovalerate & \pm & \pm & + \\
\hline Succinate & \pm & + & $\mathrm{M}$ \\
\hline Fumarate & \pm & + & + \\
\hline Glutarate & \pm & + & \pm \\
\hline Suberate & + & + & + \\
\hline Azelate & \pm & \pm & - \\
\hline Sebacate & + & + & - \\
\hline D-Malate & \pm & + & + \\
\hline L-Malate & + & + & M \\
\hline Lactate & $\mathbf{M}$ & $\mathbf{M}$ & \pm \\
\hline$\alpha$-Ketoglutarate & \pm & \pm & - \\
\hline Pyruvate & \pm & + & \pm \\
\hline Levulinate & + & + & + \\
\hline Citraconate & \pm & \pm & - \\
\hline Glycerol & - & - & $\mathbf{M}$ \\
\hline Ethanol & + & + & + \\
\hline$n$-Propanol & + & + & + \\
\hline Isopropanol & \pm & \pm & - \\
\hline Butanol & + & + & + \\
\hline Isobutanol & \pm & \pm & \pm \\
\hline Mannitol & + & + & - \\
\hline Sorbitol & \pm & + & - \\
\hline$m$-Inositol & \pm & + & M \\
\hline Adonitol & \pm & \pm & - \\
\hline Ethylene glycol & - & - & + \\
\hline Propylene glycol & \pm & + & + \\
\hline 2,3-Butylene glycol & + & + & + \\
\hline Phenol $(0.1 \%)$ & - & - & - \\
\hline Phenol $(0.05 \%)$ & - & + & + \\
\hline Protocatechuate & + & + & - \\
\hline Quinate & + & + & - \\
\hline Glycine & \pm & \pm & - \\
\hline L-Álanine & + & + & - \\
\hline Serine & + & + & - \\
\hline Threonine & \pm & \pm & \pm \\
\hline Leucine & \pm & \pm & M \\
\hline Isoleucine & M & - & + \\
\hline Valine & \pm & \pm & + \\
\hline Aspartate & + & \pm & - \\
\hline Glutamate & \pm & \pm & - \\
\hline Lysine & \pm & \pm & \pm \\
\hline Arginine & \pm & \pm & - \\
\hline Histidine & \pm & - & - \\
\hline Proline & + & \pm & \pm \\
\hline Norleucine & - & - & \pm \\
\hline$\alpha$-Aminovalerate & - & - & \pm \\
\hline$\delta$-Aminovalerate & + & + & $\mathbf{M}$ \\
\hline
\end{tabular}

TABLE 4-Continued

\begin{tabular}{lccc}
\hline Carbon source $^{a}$ & Strain PCP-I & Strain CP-2 & Strain CG-1 \\
\hline Ethanolamine & + & + & + \\
Putrescine & + & + & + \\
Spermine & + & + & + \\
Butylamine & \pm & - & - \\
Betaine & \pm & \pm & \pm \\
Sarcosine & \pm & + & - \\
Hippurate & + & + & + \\
Acetamide & + & + & + \\
Hexadecane & + & + & + \\
\hline
\end{tabular}

${ }^{a}$ The following substrates were tested but were not utilized by any of the strains: D-arabinose, L-arabinose, maltose, lactose, $\alpha$-methyl-D-glucoside, starch, 2-ketogluconate, glucuronate, saccharate, mucate, valerate, caproate, heptanoate, caprylate, caprate, malonate, maleate, adipate, pimelate, D-tartrate, Ltartrate, glycolate, glycerate, citrate, aconitate, itaconate, geraniol, D-mandelate, L-mandelate, benzoate, 2-hydroxybenzoate, 3-hydroxybenzoate, 2-hydroxybenzoate, 2-aminobenzoate, 3-aminobenzoate, 4-aminobenzoate, phthalate, naphthalene, $o$-toluate, $m$-toluate, $p$-toluate, vanillate, isovanillate, $m$-anisate, $p$-anisate, phenylacetate, $o$-hydroxyphenylacetate, 3,4-dimethoxybenzoate, $p$-hydroxyphenylacetate, $p$-cresol, toluene, $\beta$-alanine, methionine, glutamine, tyrosine, phenylalanine, tryptophan, $\alpha$-aminobutyrate, $\varepsilon$-aminocaproate, $\alpha$-amylamine, benzylamine, histamine, tryptamine, creatine, pantothenate, trigonelline, and nicotinate.

${ }_{b}+$, good growth; \pm , poor growth; - , growth not greater than the background level; $\mathrm{M}$, growth after mutation.

therefore propose that $R$. chlorophenolicus should be transferred to the genus Mycobacterium as Mycobacterium chlorophenolicum (Apajalahti et al. 1986) comb. nov.

Chemotaxonomic and growth characteristics of the M. chlorophenolicum strains are shown in Tables 2 through 4 . The $\mathrm{G}+\mathrm{C}$ contents of the DNAs range from 67 to $69 \mathrm{~mol} \%$. The genus Mycobacterium has a $\mathrm{G}+\mathrm{C}$ content range of 62 to 70 mol\% (14). Growth of the M. chlorophenolicum strains occurs at 18 to $37^{\circ} \mathrm{C}$, optimum growth occurs at $28^{\circ} \mathrm{C}$, and no growth occurs at 10 or $45^{\circ} \mathrm{C}$. Nutritional characterization revealed that the strains are very similar in their use of carbon sources (Table 4). The strains which we studied are able to degrade several chlorinated phenols, guaiacols, and syringols $(2,19,20$, 24 ), and they also O-methylate various chlorinated phenolic compounds (24); however, there are some differences in substrate specificity. The $M$. chlorophenolicum strains, as well as a strain of $M$. fortuitum (35), degrade pentachlorophenol via two hydroxylations, followed by reductive dechlorinations, producing 1,2,4-trihydroxybenzene, which is mineralized to $\mathrm{CO}_{2}(3,4,20,22,24,45,46)$. Interestingly, these polychlorophenol-degrading strains did not utilize most of the nonhalogenated aromatic compounds which we tested (Table 4).

Description of Mycobacterium chlorophenolicum comb. nov. The description below is based on data from reference 1 and on the additional information provided in this paper. Cells are gram positive and nonmotile and have a rod-to-coccus growth cycle in complex media. Colonies are yellow or orange and slightly mucoid. Growth occurs at 18,28 , and $37^{\circ} \mathrm{C}$, but not at 10 or $45^{\circ} \mathrm{C}$; optimum growth occurs at $28^{\circ} \mathrm{C}$. Pentachlorophenol and other polychlorinated phenolic compounds are degraded. The cell wall contains meso-diaminopimelic acid, arabinose, and galactose. Mycolic acids are present and contain 60 to 80 carbon atoms. Menaquinones with nine isoprenoid units and one hydrogenated double bond are predominant. The cellular fatty acids consist mainly of straight-chain saturated and monounsaturated fatty acids with 10 to 18 carbon atoms, and large amounts of 10-methyloctadecanoic acid are present. The $\mathrm{G}+\mathrm{C}$ content of the DNA is 67.5 to 69.2 mol\%. The type strain is PCP-I (= DSM 43826). 


\section{ACKNOWLEDGMENTS}

We thank Riitta Boeck for help with the fatty acid analysis, Tuire Koro for preparing thin sections, Ilkka Helander for advice concerning the sugar analyses, Brian Tindall for advice concerning the menaquinone analysis, Michael Goodfellow for donating strains, and Dieter Janke for donating Rhodococcus phage.

This work was supported in part by the Nordic Industry Fund (contract P 89050 A2.1 awarded to M.S.-S. and L.J.N.), by a grant from Nordisk Ministerråd (K.K.), and by grants R-820826 (N.J.P.) and CR-820686 (M.M.H.) from the U.S. Environmental Protection Agency.

\section{REFERENCES}

1. Apajalahti, J. H. A., P. Kärpänoja, and M. S. Salkinoja-Salonen. 1986. Rhodococcus chlorophenolicus sp. nov., a chlorophenolmineralizing actinomycete. Int. J. Syst. Bacteriol. 36:246-251.

2. Apajalahti, J. H. A., and M. S. Salkinoja-Salonen. 1986. Degradation of polychlorinated phenols by Rhodococcus chlorophenolicus. Appl. Microbiol. Biotechnol. 25:62-67.

3. Apajalahti, J. H. A., and M. S. Salkinoja-Salonen. 1987. Dechlorination and para-hydroxylation of polychlorinated phenols by Rhodococcus chlorophenolicus. J. Bacteriol. 169:675-681.

4. Apajalahti, J. H. A., and M. S. Salkinoja-Salonen. 1987. Complete dechlorination of tetrachlorohydroquinone by cell extracts of pentachlorophenol-induced Rhodococcus chlorophenolicus. J. Bacteriol. 169:5125-5130.

5. Bauchop, T., and S. R. Elsden. 1960 . The growth of microorganisms in relation to their energy supply. J. Gen. Microbiol. 23:457469.

6. Briglia, M., R. I. L. Eggen, D. J. van Elsas, and W. M. de Vos. 1994. Phylogenetic evidence for transfer of pentachlorophenol-mineralizing Rhodococcus chlorophenolicus PCP-I $\mathrm{I}^{\mathrm{T}}$ to the genus Mycobacterium. Int. J. Syst. Bacteriol. 44:494-498.

7. Collins, M. D., O. W. Howarth, E. Grund, and R. M. Kroppenstedt. 1987. Isolation and structural determination of new members of a vitamin $\mathrm{K}_{2}$ series in Nocardia brasiliensis. FEMS Microbiol. Lett. 41:35-39.

8. Collins, M. D., T. Pirouz, M. Goodfellow, and D. E. Minnikin. 1977. Distribution of menaquinones in actinomycetes and corynebacteria. J. Gen. Microbiol. 100:221-230.

9. Collins, M. D., H. N. Shah, and D. E. Minnikin. 1980. A note on the separation of natural mixtures of bacterial menaquinones using reverse phase thin-layer chromatography. J. Appl. Bacteriol. 48:277-282.

10. Deutsche Sammlung von Mikroorganismen. 1993. Catalogue of strains, 5th ed. Deutsche Sammlung von Mikroorganismen, Braunschweig, Germany.

11. Dobson, G., D. E. Minnikin, J. H. Parlett, M. Goodfellow, M. Ridell, and M. Magnusson. 1984. Systematic analysis of complex mycobacterial lipids, p. 237-265. In M. Goodfellow and D. E. Minnikin (ed.), Chemical methods in bacterial systematics. Academic Press, London.

12. Golovlev, E. L., and N. V. Eroshina. 1982. Catabolism of aromatic compounds in "erythropolis" group rhodococci. Mikrobiologiya 51:407-412.

13. Goodfellow, M. 1989. Genus Rhodococcus, p. 2362-2371. In S. T. Williams, M. E. Sharpe, and J. G. Holt (ed.), Bergey's manual of systematic bacteriology, vol. 4. Williams \& Wilkins, Baltimore.

14. Goodfellow, M. 1992. The family Nocardiaceae, p. 1188-1213. In A. Balows, H. G. Trüper, M. Dworkin, W. Harder, and K.-H. Schleifer (ed.), The prokaryotes. Springer-Verlag, New York.

15. Goodfellow, M., E. G. Thomas, A. C. Ward, and A. L. James. 1990. Classification and identification of rhodococci. Zentralbl. Bakteriol. 274:299-315.

16. Goodfellow, M., and S. T. Williams. 1983. Ecology of actinomycetes. Annu. Rev. Microbiol. 37:189-216.

17. Gorlatov, S. N., O. V. Malt'seva, V. I. Schevchenko, and L. A. Golovleva. 1989. Degradation of chlorophenols by a culture of Rhodococcus erythropolis. Mikrobiologiya 58:802-806.

18. Häggblom, M. M. 1992. Microbial breakdown of halogenated aromatic pesticides and related compounds. FEMS Microbiol. Rev. 103:29-72.

19. Häggblom, M. M., J. H. A. Apajalahti, and M. S. Salkinoja-
Salonen. 1986. Metabolism of chloroguaiacols by Rhodococcus chlorophenolicus. Appl. Microbiol. Biotechnol. 24:397-404.

20. Häggblom, M. M., J. H. A. Apajalahti, and M. S. SalkinojaSalonen. 1988. Hydroxylation and dechlorination of chlorinated guaiacols and syringols by Rhodococcus chlorophenolicus. Appl. Environ. Microbiol. 54:683-687.

21. Häggblom, M. M., D. Janke, P. J. M. Middeldorp, and M. S. Salkinoja-Salonen. 1989. O-methylation of chlorinated phenols in the genus Rhodococcus. Arch. Microbiol. 152:6-9.

22. Häggblom, M. M., D. Janke, and M. S. Salkinoja-Salonen. 1989. Hydroxylation and dechlorination of tetrachlorohydroquinone by Rhodococcus sp. strain CP-2 cell extracts. Appl. Environ. Microbiol. 55:516-519.

23. Häggblom, M. M., D. Janke, and M. S. Salkinoja-Salonen. 1989. Transformation of chlorinated phenolic compounds in the genus Rhodococcus. Microb. Ecol. 18:147-159.

24. Häggblom, M. M., L. J. Nohynek, and M. S. Salkinoja-Salonen. 1988. Degradation and O-methylation of chlorinated phenolic compounds by Rhodococcus and Mycobacterium strains. Appl. Environ. Microbiol. 54:3043-3052.

25. Janke, D., B. Schukat, and H. Prauser. 1986. Screening among nocardioform bacteria for strains able to degrade aniline and monochloroanilines. J. Basic Microbiol. 26:341-350.

26. Kaneko, T., K. Katoh, M. Fujimoto, M. Kumagai, J. Tamaoka, and Y. Katayama-Fujimura. 1986. Determination of the nucleotide composition of a deoxyribonucleic acid by high-performance liquid chromatography of its enzymatic hydrolysate: a review. J. Microbiol. Methods 4:229-240.

27. Kroppenstedt, R. M., F. Korn-Wendisch, V. J. Fowler, and E. Stackebrandt. 1981. Biochemical and molecular genetic evidence for transfer of Actinoplanes armeniacus into the family Streptomycetaceae. Zentralbl. Bakteriol. Parasitenkd. Infektionskr. Hyg. Abt. 1 Orig. Reihe C 2:254-262.

28. Lechevalier, H. A. 1989. A practical guide to generic identification of actinomycetes, p. 2344-2347. In S. T. Williams, M. E. Sharpe, and J. G. Holt (ed.), Bergey's manual of systematic bacteriology, vol. 4. Williams \& Wilkins, Baltimore.

29. Lechevalier, M. P., and H. Lechevalier. 1970. Chemical components as a criterion in the classification of aerobic actinomycetes. Int. J. Syst. Bacteriol. 20:435-444.

30. Miller, L., and T. Berger. 1985. Bacteria identification by gas chromatography of whole cell fatty acids. Gas Chromatography Applications Note 228-41. Hewlett-Packard Co., Palo Alto, Calif.

31. Minnikin, D. E., L. Alshamaony, and M. Goodfellow. 1975. Differentiation of Mycobacterium, Nocardia and related taxa by thin-layer chromatographic analysis of whole-organism methanolysates. J. Gen. Microbiol. 88:200-204.

32. Minnikin, D. E., I. G. Hutchinson, A. B. Caldicott, and M. Goodfellow. 1980. Thin layer chromatography of methanolysates of mycolic acid-containing bacteria. J. Chromatogr. 188:221-233.

33. Minnikin, D. E., S. M. Minnikin, A. G. O'Donnel, and M. Goodfellow. 1984. Extraction of mycobacterial mycolic acids and other long chain compounds by an alkaline methanolysis procedure. J. Microbiol. Methods 2:243-249.

34. Minnikin, D. E., A. G. O'Donnell, M. Goodfellow, M. Alderson, G. Athalye, A. Schaal, and J. H. Parlett. 1984. An integrated procedure for the extraction of isoprenoid quinones and polar lipids. J. Microbiol. Methods 2:233-241.

35. Nohynek, L. J., M. M. Häggblom, N. J. Palleroni, K. Kronqvist, E.-L. Nurmiaho-Lassila, and M. S. Salkinoja-Salonen. 1993. Characterization of a Mycobacterium fortuitum strain degrading polychlorinated phenolic compounds. Syst. Appl. Microbiol. 16: 126-134.

36. Palleroni, N. J., and M. Doudoroff. 1972. Some properties and taxonomic subdivisions of the genus Pseudomonas. Annu. Rev. Phytopathol. 10:73-100.

37. Prauser, H. 1976. Nocardioides, a new genus of the order Actinomycetales. Int. J. Syst. Bacteriol. 26:58-65.

38. Prosser, B., and N. J. Palleroni. 1978. Nutritional characterization of some selected actinomycetes. Int. J. Syst. Bacteriol. 28:516-522.

39. Rast, H. G., G. Engelhardt, and P. R. Wallnöfer. 1980. Degradation of aromatic compounds in the actinomycete genus Rhodococcus. FEMS Microbiol. Lett. 7:1-6. 
40. Smibert, R. M., and N. R. Krieg. 1994. Phenotypic characterization, p. 607-654. In P. Gerhardt, R. G. E. Murray, W. A. Wood, and N. R. Krieg (ed.), Methods for general and molecular bacteriology. American Society for Microbiology, Washington, D.C.

41. Stanek, J. L., and G. D. Roberts. 1974. Simplified approach to identification of aerobic actinomycetes by thin layer chromatography. Appl. Microbiol. 28:226-231.

42. Stanier, R. Y., N. J. Palleroni, and M. Doudoroff. 1966. The aerobic pseudomonads: a taxonomic study. J. Gen. Microbiol. 43:159-271.

43. Sundman, V. 1960. A description of some lignanolytic soil bacteria and their ability to oxidize simple phenolic compounds. J. Gen. Microbiol. 36:171-183.

44. Tsukamura, M., S. Mizuno, and S. Tsukamura. 1981. Numerical analysis of rapidly growing, scotochromogenic mycobacteria, including Mycobacterium obuense sp. nov., nom. rev., Mycobacterium rhodesiae sp. nov., nom. rev., Mycobacterium aichiense sp. nov., nom. rev., Mycobacterium chubuense sp. nov., nom. rev., and Mycobacterium tokaiense sp. nov., nom. rev. Int. J. Syst. Bacteriol. 31:263-275.

45. Uotila, J. S., V. H. Kitunen, T. Saastamoinen, T. Coote, M. M. Häggblom, and M. S. Salkinoja-Salonen. 1992. Characterization of aromatic dehalogenase activities of Mycobacterium fortuitum strain CG-2. J. Bacteriol. 174:5669-5675.

46. Uotila, J. S., M. S. Salkinoja-Salonen, and J. H. A. Apajalahti. 1992. Degradation of pentachlorophenol by membrane bound enzymes from Rhodococcus chlorophenolicus. Biodegradation 2:68-75.

47. Valo, R. 1990. Occurrence and metabolism of chlorophenolic wood preservative in the environment. Ph.D. thesis. University of Helsinki, Helsinki, Finland.

48. Valo, R., and M. Salkinoja-Salonen. 1986. Bioreclamation of chlorophenol-contaminated soil by composting. Appl. Microbiol. Biotechnol. 25:68-75.

49. Vestal, A. 1975. Procedures for the isolation and identification of mycobacteria. U.S. Department of Health, Education, and Welfare Publication (CDC) 75-8230. Centers for Disease Control, Atlanta.

50. Wayne, L. G., and G. P. Kubica. 1986. Genus Mycobacterium, p. 1436-1457. In P. H. A. Sneath, N. S. Mair, M. E. Sharpe, and J. G. Holt (ed.), Bergey's manual of systematic bacteriology, vol. 2. Williams \& Wilkins, Baltimore.

51. Winter, B., and W. Zimmermann. 1991. Degradation of halogenated aromatics by actinomycetes, p. 157-203. In H. Siegel (ed.), Metal ions in biological systems, vol. 2. Marcel Dekker, New York. 